\title{
Ráðstefna LÍ og WMA - lífsiðfræðin í brennidepli á Íslandi
}

Dagana 2.-4. október næstkomandi verður í fyrsta sinn haldin á Íslandi alpjóðleg ráðstefna um lífsiðfræði á vegum alpjóðasamtaka lækna (World Medical Association, WMA). Læknafélag Íslands er gestgjafi ráðstefnunnar sem haldin verður í Hörpu. Jón Snædal læknir á heiðurinn af pví að landa pessum stóra viðburði hérlendis og eiga frumkvæði að pví að WMA gefi lífsiðfræðinni aukið vægi í ráðstefnuhaldi samtakanna, sjá viðtal við hann á bls. 406.

Pó að Ísland sé sumpart afskekkt og samfélag fræðimanna lítið höfum við okkar rödd og staðsetningu sem virkar miðlandi fyrir óhlutdrægni og er mitt á milli heimsálfa.

Pegar Íslensk erfðagreining tók til starfa fyrir rúmum tveimur áratugum hófst áköf umræða á alpjóðlegum vettvangi um lífsýni, eignarhald og meðhöndlun erfðaupplýsinga, upplýst sampykki fyrir rannsóknum og fleira pví tengt. Ísland fékk par ákveðið hlutverk í miðju pessarar umræðu og athygli fræðimanna beindist í fyrsta sinn hingað par sem mikilvægir hlutir í próun lífsiðfræðinnar áttu sér stað. Fyrstu viðmið WMA í pessum efnum voru gefin út árið 2002 og eftir mikla gerjun gaf WMA út endurskoðaðar siðareglur (Taípei-yfirlýsingin 2016) um meðhöndlun lífsýna og erfðaupplýsinga í lífsýnabönkum og gagnaverum.

Orð eru jafnan til alls fyrst og pannig er pað með siðvitið. Рað hefst í hugum okkar og proskast í orðræðunni sem á sér stað, bæði fræðimanna á millum og úti í pjóðfélaginu par sem hugarleikfimi úr hægindastólum er mátuð við reynsluheiminn. Viðmið í siðferði og nálganir fólks í beitingu pess hafa breyst gríðarlega undanfarnar fjórar aldir og upp úr miðri 19. öld hafa breytingarnar orðið æ hraðari. Saga nútímalæknisfræði er álíka gömul pessum breytingum pví að pað purfti aukið frelsi í heimspekilegri hugsun til pess að raunvísindi fengju að líta dagsins ljós. Sannleikurinn um hluti í heiminum, par á meðal starfsemi líkamans, varð að fá að koma fram á sjálfstæðan máta - óháð valdhöfum, óskhyggju og hindurvitnum. Vísindi krefjast dyggða og siðferðilegs samræmis í fari rannsakandans eigi pekkingarleitin að bera árangur. Maðurinn sem pekkingarvera og siðferðisvera eru pví nátengdar. Að sama skapi parf hinn hagnýti miðlari pekkingarinnar, læknirinn, að vera siðferðilega proskaður til pess að ráðleggja viturlega veiku fólki í ýmsu ástandi og við ólíkar aðstæður, svo að vel fari. Vilhjálmur Árnason heimspekingur segir frá próun siðareglna íslenskra lækna í pessu blaði, bls. 400-3.
Tvíhyggja um líkama og sál, raunvísindi og hugvísindi, konur og karla, erfðarétt og fleira féllu hver á fæutur annarri pó að enn eimi eftir af aðskilnaði heimspeki og raunvísinda. Ein lífseigasta tvíhyggjan er að siðfræði geti ekki talist til vísinda pví að hún byggi einungis á hugmyndum manna en ekki skoðanlegum fyrirbærum í náttúrunni. Siðferði hafi ekki pá fótfestu í raunveruleikanum sem til dæmis efnaferli í líkamanum hafi. Hugmyndir séu huglægar og pekking raunvísinda hlutlæg. Ég er pessu ósammála. Pekking um hlutheiminn er einnig huglæg á pann máta að hún er huglæg mynd okkar af peim raunveruleika sem við reynum að skilja. Siðræni heimurinn er huglæg mynd okkar af pví sem við teljum breyta lífi okkar á siðferðilegan máta. Siðferði er hugtak okkar um ákveðin markmið og við skiptumst á hljóðbylgjum eða sjónrænum upplýsingum til pess að útkljá pau mál. Hljóðbylgja verður að taugaboði sem eftir vinnslu verður að ákvörðun og athöfn. Рað stýra ótal margar breytur pví hvað viljastýrð athöfn gengur út á en hið sama á við um ótal efnaferli og starfsemi líffæra - pað er skeikulleiki í bæði líf-raunvísindum og líf-hugvísindum. Viljinn er ekki ólífrænn, heldur ein ótrúlegasta birtingarmynd lífrænna ferla. Bæði lífsiðfræðin og læknisfræðin eiga pað sama markmið að vernda líf gott líf og heilsuríkt. Á pessu er enginn eðlismunur, bara mismunandi flækjustig.

Lífsiðfræðin skoðar viðfangsefni sín jafnan eftir premur megin grunngildum: frelsi, mannvirðingu og réttlæti. Í frelsinu er lögð áhersla á sjálfsákvörðunarrétt sjúklings en álitamál skapast um hann ef hæfið er skert. Í mannvirðingunni togast á griðaréttur sjúklings og verkskylda læknis eða gæðaréttur sjúklings og taumhaldsskylda læknis. Réttlætið býður okkur að veita öllum sömu pjónustu og jafnræði óháð stöðu. Svo kemur til lífpólitíkin eins og pegar læknar í hundraðatali studdu frumvarp um bann við umskurði sveinbarna. Í ljósi glæpsamlegrar hegðunar lækna víða um heim í meðferð aldraðra, fölsun rannsóknargagna, misnotkun tilraunameðferða, heilsuskrums og fleira hefur persónugerð og siðferðisprek lækna farið undir smásjána. Víða er efnt til skoðunar á gæðum siðferðis og eflingar mannkostamenntunar í læknanámi. Viðfangsefnin eru mörg. Ég hvet lækna til að nýta sér vel pann hvalreka sem pessi alpjóðaráðstefna er fyrir okkur og hittast í Hörpu 2.-4. október: medicalethicsiceland.is

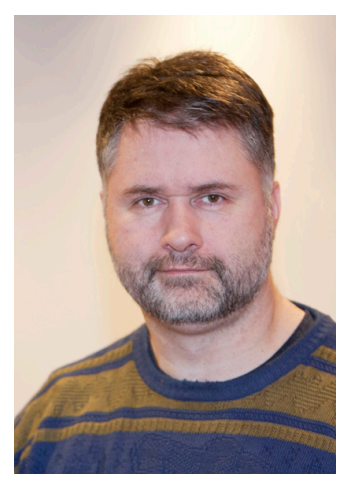

Svanur

\section{Sigurbjörnsson}

Iyflæknir og eiturefnafræðingur, formaður siðfræðiráđs Lí, aðjúnkt í siðfræði við læknadeild HÍ

svanurmd@gmail.com

\section{WMA Congress in Iceland - Bioethics in Focus}

Svanur Sigurbjörnsson, MD, BS/BA medicine/philosophy, Internist/toxicologist

Chair of the Ethical Committee of Iceland Medical Association Adjunct in medical ethics, Department of Medicine, University of Iceland

doi.org/10.17992//bl.2018.09.195 